\title{
The postglacial recolonization of Northern Europe by Rana arvalis as revealed by microsatellite and mitochondrial DNA analyses
}

\author{
T Knopp and J Merilä \\ Ecological Genetics Research Unit, Department of Biological and Environmental Sciences, University of Helsinki, Helsinki, Finland
}

\begin{abstract}
The postglacial history of the moor frog (Rana arvalis) in Northern Europe was investigated with the aid of eight variable microsatellite loci and a $661 \mathrm{bp}$ sequence of the mitochondrial cytochrome $b$ gene. A division between eastern and western mitochondrial lineages was discovered, supporting two recoIonization routes to Fennoscandia since the last glacial maximum. This result was corroborated by the microsatellite
\end{abstract}

data, which revealed a contact zone between the two lineages in Northern Sweden. These findings add to the increasing evidence that an intraspecific genetic biodiversity founded on the existence of eastern and western clades is a common element in Fennoscandian fauna and flora.

Heredity (2009) 102, 174-181; doi:10.1038/hdy.2008.91; published online 1 October 2008

Keywords: amphibia; Fennoscandia; genetic diversity; Rana arvalis; recolonization

\section{Introduction}

During the last glacial maximum, the extended Arctic ice sheet forced the Eurasian biota into Southern refugia. Fossils data and population genetic studies suggest that the peninsulas of Iberia, Italy and the Balkans acted as the main sanctuaries for many temperate species (Hewitt, 2004). As the climate warmed and the ice sheets retreated (ca 10000 years ago), the flora and fauna expanded back to their previous ranges, leading to the current phylogeographic structuring of populations (Taberlet et al., 1995; Hewitt, 1999).

In Europe, Fennoscandia was the last area to be recolonized (Lundqvist and Mejdahl, 1995). Consequently, because of their young age and the possible influence of founder events along the recolonization route, the genetic diversity of various organisms is commonly much lower in northern than in central European populations (Hewitt, 1996, 2004; Merilä et al., 1996; Palo et al., 2004). However, the withdrawal of the ice enabled two routes of recolonization into Fennoscandia, often leading to the formation of secondary contact zones (for example Hewitt, 2004) and thus increasing the overall genetic diversity found. These phylogenetic patterns have had implications not only for the patterning of within-species diversity, but also for the between-species interactions and community composition (Taberlet et al., 1995; Hewitt, 1996; Comes and Kadereit, 1998; Svenning and Skov, 2007). Therefore the identification of divergent intraspecific lineages constitutes an important element in our understanding of the

Correspondence: T Knopp, Ecological Genetics Research Unit, Department of Biological and Environmental Sciences, University of Helsinki, PO Box 65, Viikinkaari 1, Helsinki 14, Finland.

E-mail: theresa.knopp@helsinki.fi

Received 7 March 2008; revised 11 July 2008; accepted 26 July 2008; published online 1 October 2008 biogeography, evolutionary history and sometimes even adaptation of a given species.

The moor frog (Rana arvalis) is a widespread anuran species native to Eurasia. Together with Rana temporaria, it is the only frog species inhabiting the northern parts of Fennoscandia (Fog et al., 1997). Owing to its highly variable morphology and coloration, $R$. arvalis has often been the subject of studies of geographic variation and phylogeography (Stugren, 1966; Fog et al., 1997; Rafiński and Babik, 2000; Babik et al., 2004; Knopp et al., 2007). On the basis of morphological data Stugren (1966) concluded that the Scandinavian moor frogs most likely originate from the East, whereas the distribution of color morphs led Fog et al. (1997) to suggest a bidirectional recolonization of Fennoscandia. In a large-scale study of the mitochondrial phylogeography of $R$. arvalis, Babik et al. (2004) found evidence for weak differentiation among western and eastern Eurasian populations. However, as samples from northern Fennoscandia were not part of that study, the recolonization route of moor frogs to Fennoscandia remains unresolved. Moreover, although mitochondrial markers are probably more informative for investigating large-scale phylogeographic patterns, highly variable nuclear DNA markers (such as microsatellites) may actually be more informative with regard to recent events (Hewitt, 1999; Palo et al., 2004). For instance, despite one prevalent mtDNA cytochrome $b$ lineage in all Northern European countries, by using microsatellites Palo et al. (2004) were able to propose a bidirectional recolonization of $R$. temporaria to Fennoscandia.

In the current study, we used a $661 \mathrm{bp}$ fragment of the mitochondrial cytochrome $b$ gene and eight variable microsatellite loci to investigate the phylogeography of $R$. arvalis populations in Fennoscandia. In particular, we were interested in (i) testing the hypothesis (Fog et al., 1997) of a bidirectional recolonization route to 
Fennoscandia using molecular genetic evidence and (ii) comparing the results gained from mtDNA and nuclear genomes to see if they show congruent phylogeographic patterns.

\section{Materials and methods}

\section{Sampling and molecular methods}

A total of 404 samples of $R$. arvalis from Fennoscandia $(n=292)$, Russia, Ukraine and Poland $(n=112)$ were collected 1998-2005 for analysis (Figure 1; Table 1). Most samples were collected as eggs (one egg per clutch), but toe tissue collected from adults during the breeding season was also used. Samples were stored in ethanol at $+4{ }^{\circ} \mathrm{C}$ until the DNA was extracted. DNA extractions were carried out by using sodium dodecyl sulfateproteinase $\mathrm{K}$ digestion treatment followed by $\mathrm{NaCl}$ purification and isopropanol precipitation (for example Bruford et al., 1992) or by using the extraction protocol described in Elphinstone et al. (2003).

Mitochondrial DNA: An approximately $900 \mathrm{bp}$ long fragment of the mitochondrial cytochrome $b$ from 36 individuals representing 19 populations was amplified using the same primers and polymerase chain reaction (PCR) conditions as in Babik et al. (2004). The primers were ralu1 (5'-AACCTTATGACCCCAACAATACG-3'; Bos and Sites, 2001) and a modified H15502 (5'-GGG TTAGCTGGTGTAAAATTGTCTGGG-3'; Tanaka-Ueno et al., 1998). The PCRs were performed in a total volume of $20 \mu \mathrm{l}$ including ca $20 \mathrm{ng}$ of genomic DNA, $100 \mathrm{nM}$ of each primer, $250 \mu \mathrm{M}$ of each deoxyribonucleotide triphosphate, $0.5 \mathrm{U}$ AmpliTaq DNA polymerase (Applied Biosystems, Foster City, CA, USA) and $1 \times$ PCR buffer $(10 \mathrm{mM}$ Tris- $\mathrm{HCl}$, pH 8.3; $10 \mathrm{mM} \mathrm{KCl}$; $1.5 \mathrm{mM} \mathrm{MgCl}$; PE Biosystems). The cycling scheme consisted of $94{ }^{\circ} \mathrm{C}$ for $2 \mathrm{~min}$, followed by 35 cycles of $94{ }^{\circ} \mathrm{C}$ for $30 \mathrm{~s}, 56^{\circ} \mathrm{C}$ for $45 \mathrm{~s}$ and $72{ }^{\circ} \mathrm{C}$ for $1 \mathrm{~min}$, and a final extension step at $72{ }^{\circ} \mathrm{C}$ for $10 \mathrm{~min}$. The quality of the PCR products was checked on a $1.5 \%$ agarose gel electrophoresis before purification. The PCR was purified from primers and unincorporated nucleotides using ExoSAP (Amersham Biosciences, Little Chalfont, UK), sequenced in both directions using the PCR primers and BigDye Terminator sequencing kit (Applied Biosystems) and run on an ABI Prism 377 sequencer (Applied Biosystems). The sequences were manually aligned using the program Sequencher 4.1 (Gene Codes Corporation), giving a $661 \mathrm{bp}$ fragment to be analyzed in the program MEGA v.3.1 (Kumar et al., 2004). In addition to the cytochrome $b$, the $A D P / A T P$ translocase gene was sequenced (501 bp) (see methods in Matsuba et al., 2007) for 25 individuals within the study area. However, as no additional information was gained, these results are not presented.

Microsatellites: A total of eight microsatellite loci were used to analyze 20 moor frog populations (404 individuals) across Eurasia. The primers used and the corresponding PCR conditions were as follows: WRA122 and WRA6-8 (Knopp et al., 2007): initial denaturation for $3 \mathrm{~min}$ at $94^{\circ} \mathrm{C}$, followed by 35 cycles of $30 \mathrm{~s}$ at $94^{\circ} \mathrm{C}$, $30 \mathrm{~s}$ at $50{ }^{\circ} \mathrm{C}$ and $60 \mathrm{~s}$ at $72{ }^{\circ} \mathrm{C}$, and a final extension step of $10 \mathrm{~min}$ at $72{ }^{\circ} \mathrm{C}$; WRA1-160 (Knopp et al., 2007) $3 \mathrm{~min}$ at $94{ }^{\circ} \mathrm{C}$; $5 \mathrm{~s}$ at $94{ }^{\circ} \mathrm{C}, 45 \mathrm{~s}$ at $60^{\circ} \mathrm{C}, 1 \mathrm{~min}$ at $72{ }^{\circ} \mathrm{C}$ (35 cycles) and $10 \mathrm{~min}$ at $72^{\circ} \mathrm{C}$; for RCIDII (Vos et al., 2001) and Recalq (Vos et al., 2001): $3 \mathrm{~min}$ at $95^{\circ} \mathrm{C} ; 45 \mathrm{~s}$ at $55^{\circ} \mathrm{C}$ correspondingly $50{ }^{\circ} \mathrm{C}, 45 \mathrm{~s}$ at $72^{\circ} \mathrm{C}, 45 \mathrm{~s}$ at $95^{\circ} \mathrm{C}(35$ cycles); $45 \mathrm{~s}$ at $50{ }^{\circ} \mathrm{C}$ and $3 \mathrm{~min} 72^{\circ} \mathrm{C}$; Ca41 (Garner and Tomio, 2002) and Rt2Ca25 (Knopp et al., 2007): 3 min at $94{ }^{\circ} \mathrm{C}$; $30 \mathrm{~s}$ at $94,30 \mathrm{~s}$ at $60^{\circ} \mathrm{C}$ in first cycle, then lowering 0.5 per cycle, $30 \mathrm{~s}$ at $72{ }^{\circ} \mathrm{C}(20$ cycles $) ; 30 \mathrm{~s}$ at $94^{\circ} \mathrm{C}, 30 \mathrm{~s}$ at $50{ }^{\circ} \mathrm{C}, 30 \mathrm{~s}$ at $72{ }^{\circ} \mathrm{C}$ (15 cycles); and $5 \mathrm{~min}$ at $72^{\circ} \mathrm{C}$. PCR was performed in a total volume of $10 \mu \mathrm{l}$ containing: $10 \mathrm{ng}$ genomic DNA, $0.5 \mu \mathrm{M}$ of each primer, $0.25 \mu \mathrm{M}$ deoxyribonucleotides, $1.5 \mu \mathrm{M} \mathrm{MgCl}, 1 \times \mathrm{NH}_{4}$ reaction buffer and $0.1 \mathrm{U}$ BioTaq DNA polymerase (Bioline, Luckenwalde, Germany). One of each primer pair was end labeled with a fluorescent dye. Gel separation of the pooled PCR products for each individual was conducted

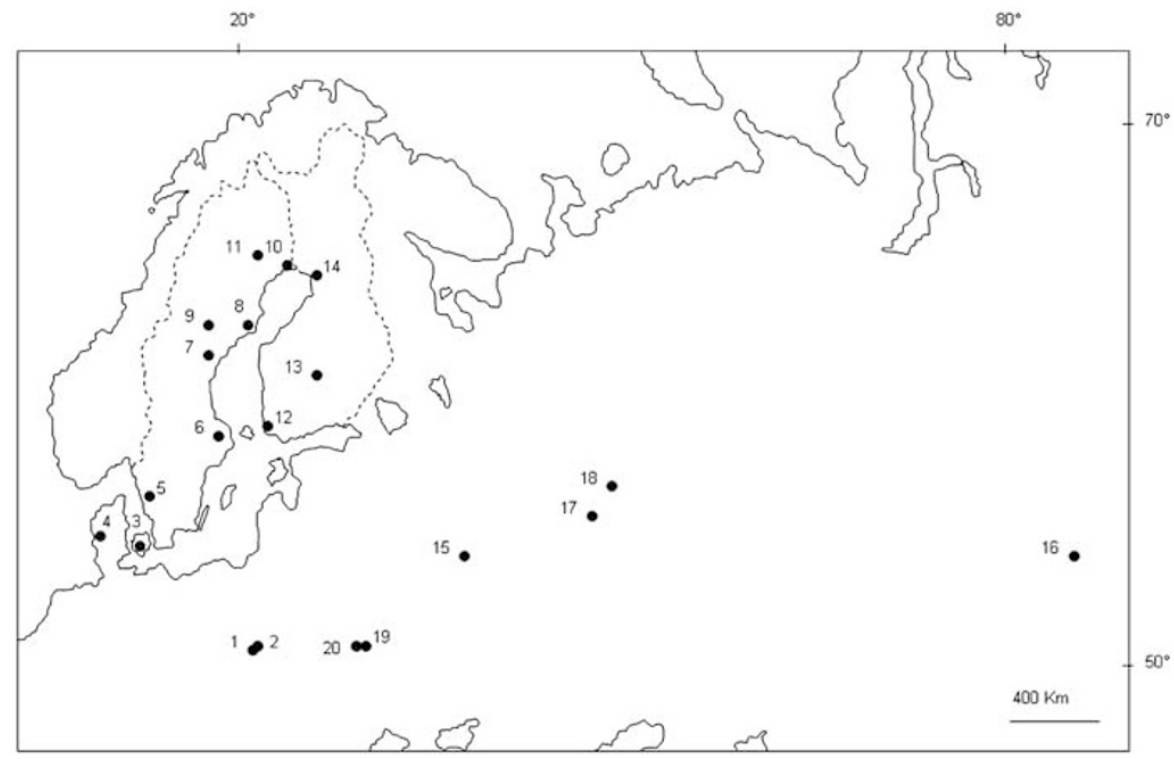

Figure 1 Map showing the location of the 20 Rana arvalis populations included in this study. The locality numbers correspond to those given in Table 1. 
Table 1 Geographical locations and basic descriptive statistics of genetic variability in the Rana arvalis samples included in this study

\begin{tabular}{|c|c|c|c|c|c|c|c|c|c|c|}
\hline Location & Population & Coordinates & $\mathrm{N}_{C y t b}$ & Haplotype & $\mathrm{N}_{m s}$ & $\mathrm{H}_{O}$ & $\mathrm{H}_{E}$ & $\mathrm{~F}_{I S}$ & $M N A$ & $\mathrm{MNA}_{C}$ \\
\hline \multicolumn{11}{|l|}{ Poland } \\
\hline 1 & Poland & $50^{\circ} \mathrm{N}, 20^{\circ} \mathrm{E}$ & 2 & $\mathrm{~A}_{1}^{\mathrm{a}}$ & 27 & 0.65 & 0.70 & 0.08 & 8.00 & 3.75 \\
\hline 2 & Dwikotzy & $50^{\circ} 44^{\prime} \mathrm{N}, 21^{\circ} 47^{\prime} \mathrm{E}$ & 2 & $\mathrm{~A}_{1}^{\mathrm{a}}$ & 19 & 0.56 & 0.66 & $0.16^{\mathrm{b}}$ & 6.88 & 3.13 \\
\hline \multicolumn{11}{|l|}{ Denmark } \\
\hline 3 & Roskilde & $55^{\circ} 40^{\prime} \mathrm{N}, 12^{\circ} 20^{\prime} \mathrm{E}$ & 2 & $\mathrm{~A}_{1}^{\mathrm{a}}$ & 27 & 0.43 & 0.47 & 0.08 & 4.38 & 3.00 \\
\hline 4 & Ringkøbing & $55^{\circ} 40^{\prime} \mathrm{N}, 09^{\circ} 18^{\prime} \mathrm{E}$ & 2 & $\mathrm{~A}_{1}^{\mathrm{a}}$ & 34 & 0.54 & 0.54 & 0.00 & 7.13 & 3.25 \\
\hline \multicolumn{11}{|l|}{ Sweden } \\
\hline 5 & Tottatjärn & $57^{\circ} 36^{\prime} \mathrm{N}, 12^{\circ} 34^{\prime} \mathrm{E}$ & 2 & $\mathrm{~A}_{1}^{\mathrm{a}}$ & 40 & 0.63 & 0.60 & -0.06 & 3.13 & 3.13 \\
\hline 6 & Andersboån & $60^{\circ} 18^{\prime} \mathrm{N}, 17^{\circ} 09^{\prime} \mathrm{E}$ & 2 & $\mathrm{~A}_{1}^{\mathrm{a}}, \mathrm{A}_{24}{ }^{\mathrm{a}}$ & 39 & 0.59 & 0.58 & -0.02 & 7.13 & 2.50 \\
\hline 7 & Fågelharen & $62^{\circ} 06^{\prime} \mathrm{N}, 17^{\circ} 28^{\prime} \mathrm{E}$ & 2 & $\mathrm{~A}_{1}^{\mathrm{a}}$ & 27 & 0.27 & 0.27 & 0.03 & 3.25 & 1.88 \\
\hline 8 & Röttjärn & $63^{\circ} 42^{\prime} \mathrm{N}, 16^{\circ} 47^{\prime} \mathrm{E}$ & 2 & RA1 & 29 & 0.30 & 0.32 & 0.05 & 2.88 & 2.00 \\
\hline 9 & Trekärringmyren & $63^{\circ} 43^{\prime} \mathrm{N}, 20^{\circ} 10^{\prime} \mathrm{E}$ & 2 & $\mathrm{~A}_{1}^{\mathrm{a}}$ & 28 & 0.42 & 0.41 & -0.02 & 3.50 & 2.50 \\
\hline 10 & Kalix & $65^{\circ} \mathrm{N}, 23^{\circ} \mathrm{E}$ & 2 & $\mathrm{~A}_{2}^{\mathrm{a}}$ & 12 & 0.39 & 0.38 & -0.02 & 3.13 & 2.00 \\
\hline 11 & Vuollerim & $66^{\circ} 26^{\prime} \mathrm{N}, 20^{\circ} 36^{\prime} \mathrm{E}$ & 2 & $\mathrm{~A}_{7}^{\mathrm{a}}$ & 6 & 0.43 & 0.41 & -0.06 & 3.00 & 2.75 \\
\hline \multicolumn{11}{|l|}{ Finland } \\
\hline 12 & Perniö & $60^{\circ} \mathrm{N}, 23^{\circ} \mathrm{E}$ & 2 & $\mathrm{~A}_{2}{ }^{\mathrm{a}}, \mathrm{RA} 2$ & 29 & 0.44 & 0.43 & -0.01 & 3.75 & 2.38 \\
\hline 13 & Jyväskylä & $62^{\circ} 13^{\prime} \mathrm{N}, 25^{\circ} 41^{\prime} \mathrm{E}$ & 2 & $\mathrm{~A}_{2}{ }^{\mathrm{a}}, \mathrm{RA} 3$ & 14 & 0.31 & 0.36 & 0.14 & 2.75 & 2.00 \\
\hline 14 & Liminka & $64^{\circ} 53^{\prime} \mathrm{N}, 25^{\circ} 33^{\prime} \mathrm{E}$ & 2 & $\mathrm{~A}_{2}^{\mathrm{a}}, \mathrm{RA} 4$ & 7 & 0.40 & 0.40 & 0.01 & 2.88 & 2.63 \\
\hline \multicolumn{11}{|l|}{ Russia } \\
\hline 15 & Moskovskaya & $55^{\circ} 24^{\prime} \mathrm{N}, 37^{\circ} 47^{\prime} \mathrm{E}$ & - & & 24 & 0.45 & 0.49 & 0.08 & 4.88 & 2.63 \\
\hline 16 & Tomskaya & $56^{\circ} 30^{\prime} \mathrm{N}, 84^{\circ} 53^{\prime} \mathrm{E}$ & 1 & $\mathrm{~A}_{2}{ }^{\mathrm{a}}$ & 10 & 0.43 & 0.48 & 0.12 & 3.63 & 2.63 \\
\hline 17 & Nizhegorodskaya & $57^{\circ} 52^{\prime} \mathrm{N}, 47^{\circ} 07^{\prime} \mathrm{E}$ & 1 & $\mathrm{~A}_{2}{ }^{a}$ & 10 & 0.44 & 0.50 & 0.12 & 3.38 & 2.63 \\
\hline 18 & Kironovskaya & $58^{\circ} 40^{\prime} \mathrm{N}, 49^{\circ} 05^{\prime} \mathrm{E}$ & 2 & $\mathrm{~A}_{7}^{\mathrm{a}}$ & 12 & 0.45 & 0.50 & 0.09 & 3.63 & 2.75 \\
\hline \multicolumn{11}{|c|}{ The Ukraine } \\
\hline 19 & Krasno village & $51^{\circ} 28^{\prime} \mathrm{N}, 30^{\circ} 07^{\prime} \mathrm{E}$ & 2 & $\mathrm{~A}_{7}{ }^{\mathrm{a}}, \mathrm{RA} 5$ & 6 & 0.43 & 0.56 & 0.24 & 3.25 & 2.75 \\
\hline 20 & Lake Gluboky & $51^{\circ} 26^{\prime} \mathrm{N}, 30^{\circ} 03^{\prime} \mathrm{E}$ & 2 & $\mathrm{~A}_{7}^{\mathrm{a}}$ & 4 & 0.34 & 0.56 & 0.39 & 2.63 & 2.63 \\
\hline Totally & & & 36 & 9 & 404 & & & & & \\
\hline
\end{tabular}

Abbreviations: Haplotypes, the haplotypes detected in each population; $H_{\mathrm{E}}$, expected heterozygosity; $H_{\mathrm{O}}$, observed heterozygosity; MNA, mean number of microsatellite alleles; $M N A_{\mathrm{C}}$, MNA corrected for unequal sample sizes; $N_{\text {cytb }}$, the number of individuals sequenced for cytochrome $b ; N_{\mathrm{ms}}$, the number of individuals genotyped for microsatellites.

${ }^{a}$ Haplotypes described in Babik et al. (2004).

bignificant deviation from Hardy-Weinberg equilibrium.

with a MegaBACE 1000 (Amersham Biosciences) automated capillary DNA-sequencer. Data collection and individual allele scoring were carried out with Fragment Profiler software (version 1.2; Amersham Biosciences).

\section{Data analysis of microsatellite loci}

Linkage disequilibrium between loci and possible deviations from Hardy-Weinberg $(\mathrm{H}-\mathrm{W})$ equilibrium were tested by the Markov chain method as implemented in the program GENEPOP 3.4 (Raymond and Rousset, 1995). Applying the same program, the observed $\left(H_{\mathrm{O}}\right)$ and expected $\left(H_{\mathrm{E}}\right)$ heterozygosity and the corresponding inbreeding coefficient $\left(F_{\mathrm{IS}}\right)$ per population were calculated (Weir and Cockerham, 1984).

Population structure was assessed using three different approaches. Firstly, the pairwise differentiation among populations was estimated by $F_{\mathrm{ST}}$ (that is $\theta$; Weir and Cockerham, 1984) using the program FSTAT (Goudet, 1995) and visualized in a multidimensional scaling plot. Secondly, a neighbor-joining tree was constructed based on Neis $D_{a}$ distances (Nei et al., 1983). This method has proven to perform well in phylogenetic analyses, especially when a large number of loci are used (Takezaki and Nei, 1996). Construction of the tree was performed with POPULATIONS 1.2.28
(Langella, 2002) where the reliability of the tree was evaluated by bootstrapping over loci (10000 replicates). Lastly, for the purpose of examining the origin of the northernmost populations (Vuollerim, Kalix, Trekärringmyren, Röttjärn, Fågelharen, Liminka and Jyväskylä) an assignment test based on genotype frequencies was conducted using the program GENECLASS 2.0 (Cornuet and Luikart, 1996). Here individuals with 'unknown origin' may be assigned to a reference population according to the log (likelihood) value (Paetkau et al., 1995) estimated for it. In our tests, the northernmost populations were excluded from the reference populations. Thus, the northern individuals must be assigned to any other population. Given the results obtained from analyses of mtDNA data, the genetic contribution of each haplotype lineage to the northern populations was then estimated from the proportion of individuals assigned to each of the mtDNA lineages (that is a population harboring a specific mtDNA lineage).

\section{Results}

\section{Mitochondrial DNA}

The $661 \mathrm{bp}$ fragment of cytochrome $b$ examined from $R$. arvalis included nine polymorphic sites defining nine haplotypes (Table 2). Four of the haplotypes have been 
described earlier (Babik et al., 2004), whereas five new ones were discovered (RA1-RA5, GenBank accession numbers EU523748-EU523752). All haplotypes differed from each other by one or two codon substitutions (Table 2). In Fennoscandia mtDNA haplotype diversity was high, with a total of seven haplotypes found (Tables 1 and 2; Figure 3b). Phylogenetic analyses of all populations revealed weak structuring, but three major haplotype lineages were still apparent (Figures 2 and 3a). Most notably, all the Finnish populations and the two northernmost Swedish populations (Kalix and Vuollerim) were part of the more eastern haplotype lineages $\left(A_{2}\right.$ and $A_{7}$ ), whereas the rest of Fennoscandia belonged to a western lineage $\left(A_{1}\right.$; Figure $\left.3 b\right)$.

Table 2 Moor frog mtDNA haplotypes, their variable positions and frequencies $(N)$

\begin{tabular}{|c|c|c|c|c|c|c|c|c|c|c|}
\hline \multirow[t]{2}{*}{ Haplotype } & \multicolumn{9}{|c|}{ Site position } & \multirow[t]{2}{*}{$\mathrm{N}$} \\
\hline & 81, & 143, & 176 & 254 & 279 & 407, & 443 & 487 & 612 & \\
\hline $\mathrm{A}_{1}$ & G & $\mathrm{T}$ & A & $\mathrm{T}$ & A & A & A & $\mathrm{C}$ & $\mathrm{T}$ & 15 \\
\hline $\mathrm{A}_{24}$ & & . & $\cdot$ & . & & G & . & . & . & 1 \\
\hline RA1 & A & . & . & & G & & . & . & & 2 \\
\hline $\mathrm{A}_{2}$ & . & . & $\cdot$ & C & r. & . & & . & . & 7 \\
\hline RA2 & . & . & . & C & . & . & G & . & . & 1 \\
\hline RA3 & . & 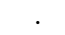 & G & C & . & . & . & . & . & 1 \\
\hline RA4 &. & $\mathrm{C}$ & . & $\mathrm{C}$ & . & . & . & . & . & 1 \\
\hline $\mathrm{A}_{7}$ & . & . & . & . & . & . & . & $\mathrm{T}$ & & 7 \\
\hline RA5 & . & . & . & . & . & . & . & $\mathrm{T}$ & C & 1 \\
\hline
\end{tabular}

The total nucleotide diversity $(\pi)=0.0019$.

\section{Microsatellites}

All eight microsatellite loci amplified well in all the populations, the amplification success varying between 82\% (RtCa25) and 97\% (Recalq) for the different loci. A total of 119 alleles were found, with an average of 35 alleles per population. There were no signs of linkage disequilibrium between the loci $(P>0.29)$ and after applying sequential Bonferroni correction (Rice, 1989), no deviations from $\mathrm{H}-\mathrm{W}$ equilibrium were discovered except for one population (Table 1).

When using microsatellite data to examine the phylogenetic relationships among populations, all the different tests gave qualitatively similar results. In concordance with the mitochondrial data, the populations clustered into a western and an eastern group. This was seen both in the multidimensional scaling plot based on $F_{\mathrm{ST}}$ values (Figure 4) and in the Neighbor-joining tree based on Neis $D_{\text {a }}$ distance (Figure 2). In this tree, the western group included the Danish and most of the Swedish populations. The samples from Finland, Russia and Ukraine clustered together as an eastern group. The Polish samples clustered separately in between the western and eastern lineages. Most notably, the Northern Swedish population Kalix clustered together with the Finnish populations whereas the Vuollerim sample was placed on a branch of its own (Figure 2). Albeit the statistical support was poor, these observations are consistent with the bidirectional recolonization hypothesis with a hybrid zone situated in northernmost Sweden. Support for a hybrid zone in Northern Sweden was further obtained from the assignment test. When assigning (Paetkau et al., 1995) individuals from the northernmost populations (Vuollerim, Kalix, Trekärringmyren, Röttjärn, Fågelharen, Liminka and
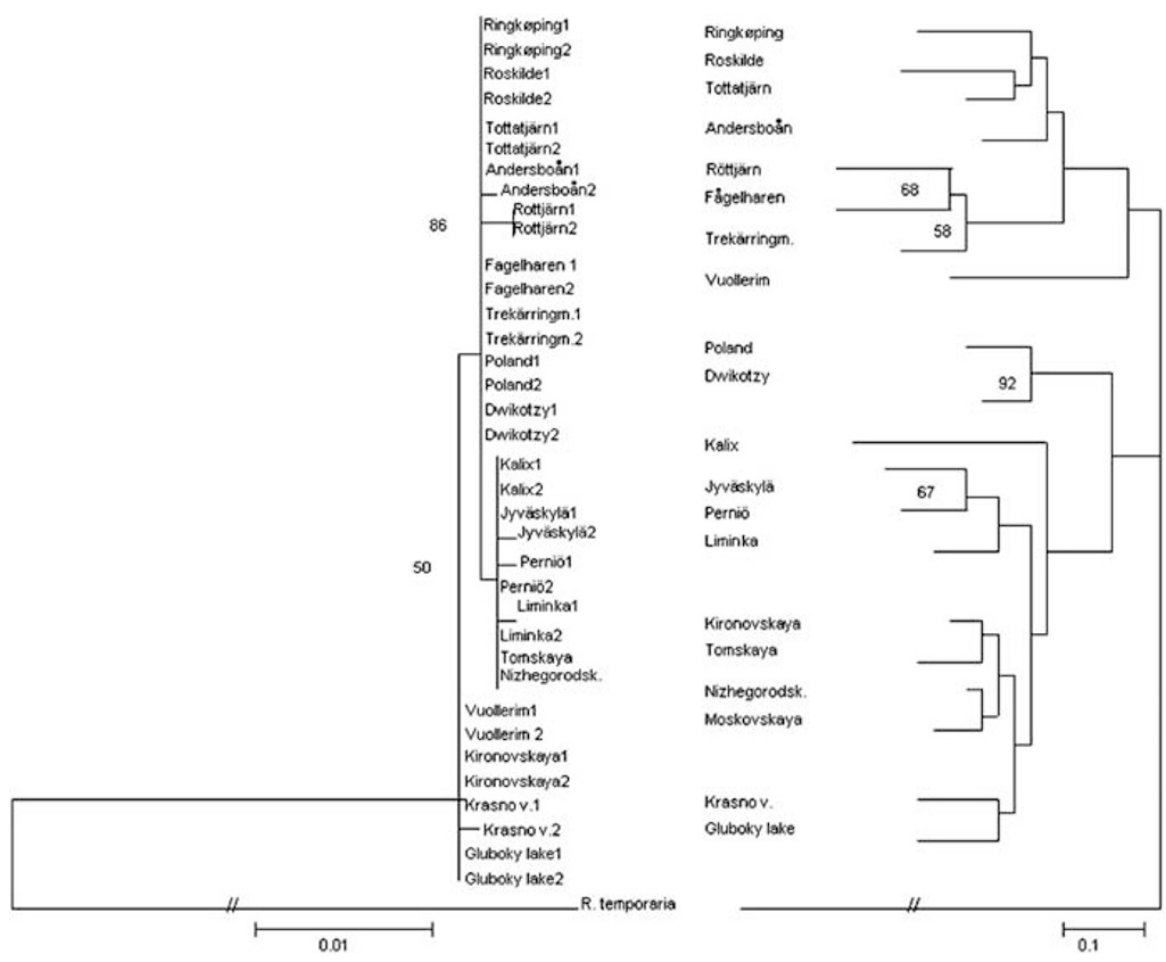

Figure 2 Neighbor-joining trees based on $661 \mathrm{bp}$ of Cyt- $b$ sequence (left) and eight microsatellite loci (right, Nei et al., 1983) for Rana arvalis populations across Eurasia. Both trees are rooted with corresponding data from four Rana temporaria individuals. Bootstrap support $>50 \%$ is shown. 

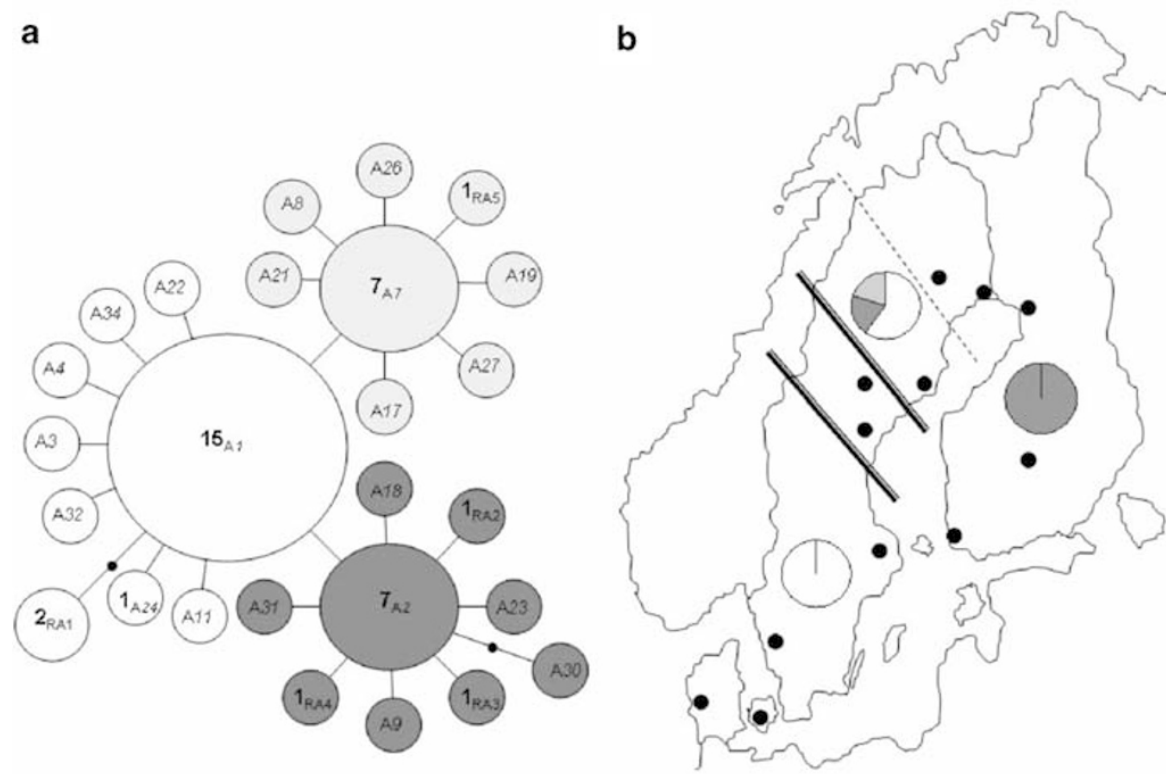

Figure 3 (a) A haplotype network (Clement et al., 2000) for Rana arvalis cytochrome $b(661 \mathrm{bp})$ observed outside the Carpathian Basin. A line indicates $1 \mathrm{bp}$ difference. AN refer to haplotypes described in Babik et al. (2004) (21 haplotypes in total), RA1-RA5 are new haplotypes discovered in the current study, numbers in bold refer to the amount of individuals found of a specific haplotype (36 individuals in total), (b) The geographic distribution of the three haplotype lineages within Fennoscandia and the approximate position of the discovered contact zone between the western and eastern $R$. arvalis mitochondrial lineages are indicated with a thin dotted line. The thick lines represent the two most common hybrid zones for other species in Fennoscandia (after Hewitt, 1999).

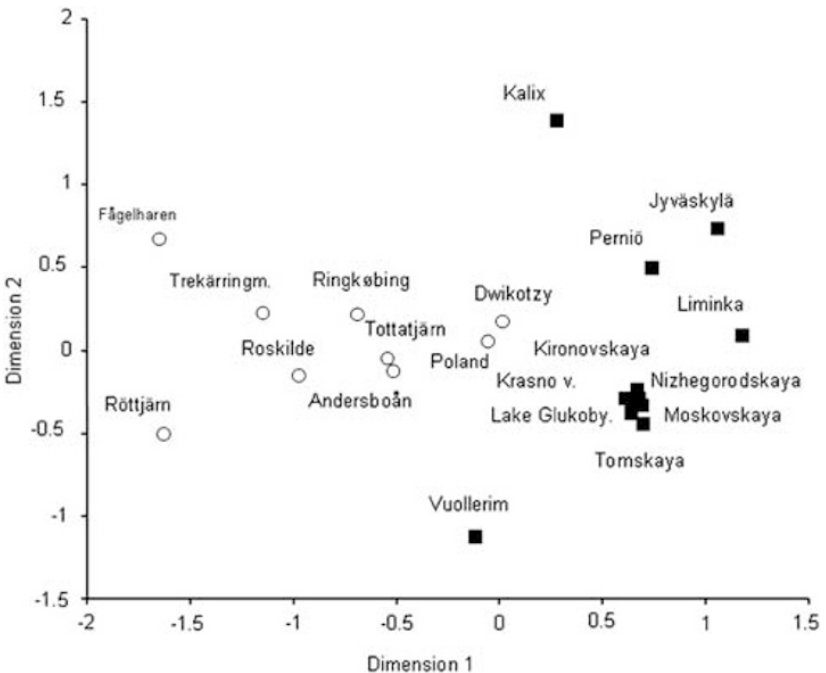

Figure 4 A multidimensional scaling plot of pairwise microsatellite $F_{\mathrm{ST}}$ distances between study populations (D-hat: raw stress $=3.15$, stress $=0.09)$. $\bigcirc$ and $\boldsymbol{\square}$ indicate populations harboring the western or eastern Cyt- $b$ haplotype lineages, respectively.

Jyväskylä) to reference populations representing either eastern or western mtDNA haplotypes, individuals from Vuollerim failed to be allocated to any specific group (Figure 5). Individuals from Jyväskylä, Liminka and Kalix were assigned to populations with an eastern mtDNA haplotype whereas all the rest were assigned to a western lineage (Figure 5).

\section{Discussion}

The postglacial recolonization patterns of animal and plant species inhabiting the Northern hemisphere-as

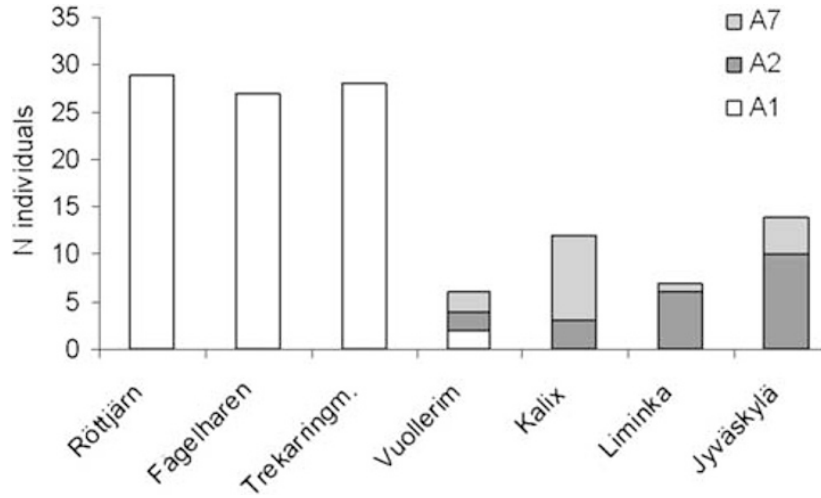

Figure 5 Assignment test results showing the number of individuals from the northernmost populations assigned to any reference population (see text) of a western $\left(A_{1}\right)$ or eastern $\left(A_{2}, A_{7}\right)$ cytochrome $b$ haplotype.

reflected in molecular markers-have been in the focus of active research ever since the early 1990s (reviews in Jaarola et al., 1999; Avise, 2000; Hewitt, 2004). It has become clear that the recolonization events have sometimes been complex, having major effects on the phylogenetic structuring of European biota (reviewed in Hewitt, 1996; Comes and Kadereit, 1998). In Scandinavia, the prevalent determinant of the timing and patterning of phylogeographic case histories appears to have been the retreat of the ice sheet situated in Northern Sweden (Lundqvist and Mejdahl, 1995). It prevented movement between the western and eastern parts of Fennoscandia, and hence, when the ice melted, divergent genetic lineages were able to come into secondary contact. For several terrestrial and aquatic organisms, suture zones in Central (for example Taberlet et al., 1995) or Northern Sweden (for example Kontula and Väinölä, 2001) have 
been identified. This repeated pattern signifies a common bidirectional colonization history of Scandinavia, where individuals originate from a single (Erinaceus europaeus: Santucci et al., 1998; Microtus oeconomus: Brunhoff et al., 2006; Fucus serratus: Hoarau et al., 2007) or several refugial areas (Ursus arctos: Taberlet et al., 1995; Cottus gobio: Kontula and Väinölä, 2001; Microtus agrestis: Jaarola and Searle, 2002; Betula pendula: Palmé et al., 2003; Vipera berus: Carlsson et al., 2004; Gasterosteus aculeatus: Mäkinen et al., 2006).

\section{Recolonization of Fennoscandia by Rana arvalis}

Earlier moor frog studies (Rafiński and Babik, 2000; Babik et al., 2004) have identified three major mtDNA clades within the species range. Two of the clades are restricted within the Carpathian Basin (B and AII in Babik et al., 2004), whereas the third clade (AI) is found across the rest of Eurasia. The Eurasian clade (AI) can moreover be separated into three major haplotype lineages; $\mathrm{A}_{1} \mathrm{~A}_{2}$ and $\mathrm{A}_{7}$ (Figure 3a; Babik et al., 2004), and even though the haplotype lineages in many parts overlap each other, a slight east-west separation can be identified. Thus, given a phylogenetic structuring like this, it has been suggested that the moor frog survived the last glacial period in multiple refugial areas (Rafiński and Babik, 2000; Babik et al., 2004). Haplotype lineage $\mathrm{A}_{1}$ (from clade $\mathrm{AI}$ ) is believed to have survived in the Carpathian Basin together with the two other clades (B and AII). But as opposed to clade B and AII, haplotype $A_{1}$ spread to the north and colonized western parts of Europe. The other two haplotype lineages $\left(A_{2}\right.$ and $\left.A_{7}\right)$ from clade $\mathrm{AI}$ can also be found in the west, but they are more widespread in the eastern parts. Therefore, a refugium situated in south-eastern Russia-or even further east in Siberia or Kazakhstan-has been suggested (Rafiński and Babik, 2000; Babik et al., 2004).

In the present study, we found representatives of all the three haplotype lineages from the AI clade in Scandinavia. Moreover, the phylogeographic patterns observed in the mitochondrial data were, to large extents, supported by the data from nuclear microsatellites. In both of the constructed trees, the basal nodes obtained low bootstrap support, however, a rather clear east (Finland, Russia, Ukraine)-west (Sweden, Denmark) separation was observed within Fennoscandia. All Finnish haplotypes together with the northern Swedish Kalix population were part of the eastern $A_{2}$ lineage, whereas the more southerly Swedish populations, along with Denmark, belonged to the western $\mathrm{A}_{1}$ lineage. The largest difference between the two trees constructed was seen for the Polish and Vuollerim samples. Whereas mitochondrial data grouped Poland with Sweden, it was set between the western and eastern lineages in the microsatellite tree (Figure 2). However, in assignment and structure tests the Polish samples clustered with Sweden rather than with Finland, indicating a closer common ancestral association between the two former areas. Vuollerim, on the other hand, was the only Nordic population having the $A_{7}$ haplotype (otherwise found in the Ukraine and in one Russian location), but based on genotype frequencies, individuals from Vuollerim failed to be assigned to the correct mtDNA lineage. In fact, Vuollerim seemed to be a mixture of individuals from all the three mtDNA lineages, indicating that this area could represent a hybrid zone where the western and eastern
$R$. arvalis lineages have met after the last ice age. Moreover, if we accept the expectations of a rapid colonization, then the last populations to be colonized should have the lowest genetic diversity (Hewitt, 2004) and in a possible contact zone, the genetic diversity should rise because of hybridization of different haplotypes. Indeed, the assignment results are supported by the low genetic diversity found on both sides of Vuollerim, verifying this area to be the hybrid zone of the differentiated recolonization lineages of $R$. arvalis.

These results, based on genetic data, are not supported by the distribution of different color morphs in Fennoscandia. According to Fog et al. (1997) the maculata form dominates in Southern and Central Sweden, as well as in Southern Finland, whereas striata predominates in the northernmost regions. However, our results suggest that individuals from Southern Sweden and Finland are clearly differentiated in terms of allele frequencies, and also, belong to divergent mitochondrial lineages. Therefore, the lack of concurrence between genetic and phenotypic data suggests that either direct environmental influences (phenotypic plasticity) or natural selection acting on coloration may be responsible for the observed phenotypic patterning. This type of mismatch between genetic and phenotypic data is not unexpected, and in fact, perhaps a rule rather than an exception (Leinonen et al., 2008).

In terms of mitochondrial haplotype diversity, $R$. arvalis appears to be more variable than the only other anuran amphibian ( $R$. temporaria) found in Northern Fennoscandia (Palo et al., 2004). It should be noted however, that the analyses of $R$. temporaria were carried out on a shorter fragment of cytochrome $b(440 \mathrm{bp}$, Palo et al., 2004), and the failure to find more than one haplotype in Fennoscandian common frogs might be affected by this limitation. However, in a geographical distance of more than $2000 \mathrm{~km}$, our discovery of seven polymorphic sites in a set of $661 \mathrm{bp}$ sequence is still quite low. This might be because of the small sample sizes used in our dataset, but in the light of results by Babik et al. (2004), it seems unlikely that our conclusions on a bidirectional colonization of Scandinavia would have changed using larger sample sizes.

\section{Hybrid zones in Fennoscandia}

The position of the final ice sheet to melt constitutes a natural location for divergent colonization lineages to meet. Consequently, the hybrid zones for several species in Fennoscandia are located close to the proposed contact zone of $R$. arvalis in Northern Sweden (Figure 3b, Hewitt, 1999). Moreover, for many of the smaller terrestrial animals examined in Scandinavia, along with the moor frog (Babik et al., 2004), one or several refugia in the eastern parts of Eurasia has been suggested (Cooper et al., 1995; Fedorov et al., 1996; Jaarola and Searle, 2002; Palo et al., 2004; Ursenbacher et al., 2006). A more western refugium seems less common (for example Seddon et al., 2001). Nevertheless, a divergent colonization inevitably leads to increased allelic diversity within a species. As populations deriving from altered refugia will possess different alleles with potentially dissimilar abilities for adaptation, this might affect the species survival in varying environments (Liukkonen-Anttila et al., 2002). Also, with differing alleles, the genetic distance between 
neighboring populations in the suture zone might be higher than expected by geographic distance alone. This was clearly seen in our results. The moor frogs from Finland were genetically much closer to the geographically distant Russian populations than to the Central Swedish ones. This particular phylogenetic finding becomes important in a conservation context (Ryder, 1986), as the identification of multiple genetic lineages is of great importance, especially when dealing with a protected species such as the moor frog (cf Appendix II of Bern Convention, 1979).

\section{Conclusions}

Based on the data from both mtDNA and nuclear markers, our results suggest a bidirectional recolonization route of $R$. arvalis to Fennoscandia since the last glacial period. One lineage is thought to have derived from a refugium in the Carpathians, coming by Denmark to Southern Sweden. Another lineage probably arrived from an eastern refugium via Finland to northernmost Sweden. The contact zone between the two lineages is situated in Northern Sweden, close to the location of the hybrid zones observed in several other species.

\section{Acknowledgements}

We thank the following people for providing us with samples: Paul Arens, Wieslaw Babik, Markus Johansson, Panu Keihäs, Sergius Kuzmin, Anssi Laurila, David Lesbarrères, Tim Mousseau, Martti Niskanen, Jan Rafiński, Katja Räsänen, Pirkko Siikamäki, Fredrik Söderman and Claire Vos. We remain in gratitude to Jukka Palo and Craig Primmer for their help at various stages of this study. Funding for this study was obtained from the Swedish Natural Science Research Council (JM), the Academy of Finland (TK, JM), the Antti and Jenny Wihuri Foundation (TK), Oskar Öflunds stiftelse (TK), University of Helsinki Science Foundation (JM) and Otto A Malms donationsfond (TK).

\section{References}

Avise JC (2000). Phylogeography: the History and Formation of Species. Harvard University Press: Cambridge, MA.

Babik W, Branicki W, Sandera M, Litvinchuk S, Borkin J, Irwin T et al. (2004). Mitochondrial phylogeography of the moor frog, Rana arvalis. Mol Ecol 13: 1469-1480.

Bern convention (1979). Convention on the Conservation of European wildlife and Natural Habitats. Convention relative à la conservation de la vie sauvage et du milieu de l'Europe Appendix II, Bern/Berne, 19.IX.1979.

Bos DH, Sites JW (2001). Phylogeography and conservation genetics of the Columbia spotted frog (Rana luteiventris; Amphibia, Ranidae). Mol Ecol 10: 1499-1513.

Bruford MW, Hanotte O, Brookefield JFY, Burke T (1992). Single-locus and multi-locus DNA finger printing. In: Hoelzel AR (ed). Molecular Genetic Analysis of Populations. pp 225-269. IRL Press: Oxford.

Brunhoff C, Yoccoz NG, Ims RA, Jaarola M (2006). Glacial survival or late glacial colonization? Phylogeography of the root vole (Microtus oeconomus) in north-west Norway. J Biogeogr 33: 2136-2144.

Carlsson M, Söderberg L, Tegelström H (2004). The genetic structure of adders (Vipera berus) in Fennoscandia: congruence between different kinds of genetic markers. Mol Ecol 13: 3147-3152.
Clement M, Posada D, Crandall KA (2000). TCS: a computer program to estimate gene genealogies. Mol Ecol 9: 1657-1660.

Comes HP, Kadereit JW (1998). The effect of Quaternary climatic changes on plant distribution and evolution. Trends Plant Sci 3: 432-438.

Cooper SJB, Ibrahim KM, Hewitt GM (1995). Postglacial expansion and genome subdivision in the European grasshopper Chorthippus parallelus. Mol Ecol 4: 49-60.

Cornuet JM, Luikart G (1996). Description and power analysis of two tests for detecting recent population bottlenecks from allele frequency data. Genetics 144: 2001-2014.

Elphinstone MS, Hinten GN, Anderson MJ (2003). An inexpensive and high-throughput procedure to extract and purify total genomic DNA for population studies. Mol Ecol Notes 3: 317-320.

Fedorov V, Jaarola M, Fredga K (1996). Low mitochondrial DNA variation and recent colonization of Scandinavia by the wood lemming Myopus schisticolor. Mol Ecol 5: 577-581.

Fog K, Schmedes A, Rosen $\varnothing$ rn de Lasson D (1997). Nordens padder og krybdyr. Gads Forlag: Copenhagen.

Garner TWJ, Tomio G (2002). Microsatellites for use in studies of the Italian Agile Frog, Rana latastei (Boulenger). Conserv Genet 2: 77-80.

Goudet J (1995). FSTAT (vers.1.2): a computer program to calculate F-statistics. J Hered 86: 485-486.

Hewitt GM (1996). Some genetic consequences of ice ages, and their role in divergence and speciation. Biol J Linnean Soc 58: 247-276.

Hewitt GM (1999). Post-glacial re-colonization of European biota. Biol J Linnean Soc 68: 87-112.

Hewitt GM (2004). The structure of biodiversity-insights from molecular phylogeography. Front Zool 1: 4.

Hoarau G, Coyer JA, Veldsink JH, Stam WT, Olsen JL (2007). Glacial refugia and recolonization pathways in the brown seaweed Fucus serratus. Mol Ecol 16: 3606-3616.

Jaarola M, Searle JB (2002). Phylogeoraphy of field voles (Microtus argestis) in Eurasia inferred from mitochondrial DNA sequences. Mol Ecol 11: 2613-2621.

Jaarola M, Tegelström H, Fredga K (1999). Colonization history in Fennoscandian rodents. Biol J Linn Soc 68: 113-127.

Knopp T, Cano JM, Crochet P-A, Merilä J (2007). Contrasting levels of variation in neutral and quantitative genetic loci on island populations of Moor frogs (Rana arvalis). Conserv Genet 8: $45-56$

Kontula T, Väinölä R (2001). Postglacial colonization of Northern Europe by distinct phylogeographic lineages of the bullhead, Cottos gobio. Mol Ecol 10: 1983-2002.

Kumar S, Tamura K, Nei M (2004). MEGA3: integrated software for molecular evolutionary genetics analysis and sequence alignment. Brief Bioinform 5: 150-163.

Langella O (2002). Population 1.2.28. Logiciel de génétique des populations. Laboratoire Populations, génétique et évolution, CNRS UPR 9034, Gif-sur-Yvette, http:/ / www.cnrs-gif.fr/pge/.

Leinonen T, Cano JM, O'Hara R, Merilä J (2008). Comparative studies of quantitative trait and neutral marker divergence: a meta-analysis. I Evol Biol 21: 1-17.

Liukkonen-Anttila T, Uimaniemi L, Orell M, Lumme J (2002). Mitochondrial DNA variation and the phylogeography of the grey partridge (Perdix perdix) in Europe: from Pleistocene history to present day populations. J Evol Biol 15: 971-982.

Lundqvist J, Mejdahl V (1995). Luminescence dating of the deglaciation in northern Sweden. Quat Int 28: 193-197.

Mäkinen HS, Cano MS, Merilä J (2006). Genetic relationships among marine and freshwater populations of the European three-spined stickleback (Gasterosteus aculeatus) revealed by microsatellites. Mol Ecol 15: 1519-1534.

Matsuba C, Palo JU, Kuzmin SL, Merilä J (2007). Evidence for multiple retroposition events and gene evolution in the ADP/ATP translocase gene family in Ranid frogs. J Hered 98 : 300-310. 
Merilä J, Björklund M, Baker AJ (1996). Genetic population structure and gradual northward decline of genetic variability in the greenfinch (Carduelis chloris). Evolution 50: 2548-2557.

Nei M, Tajima F, Tateno Y (1983). Accuracy of estimated phylogenetic trees from molecular data. J Mol Evol 19: 153-170.

Paetkau D, Calvert W, Stirling I, Strobeck C (1995). Microsatellite analysis of population structure in Canadian polar bears. Mol Ecol 4: 347-354.

Palmé AE, Su Q, Rautenberg A, Manni F, Lascoux M (2003). Postglacial recolonization and cpDNA variation of silver birch, Betula pendula. Mol Ecol 12: 201-212.

Palo JU, Schmeller D, Laurila A, Primmer CR, Kuzmins SI, Merilä J (2004). High degree of population subdivision in a widespread amphibian. Mol Ecol 13: 2631-2644.

Rafiński J, Babik W (2000). Genetic differentiation among northern and southern populations of the moor frog Rana arvalis Nilsson in central Europe. Heredity 84: 610-618.

Raymond M, Rousset F (1995). GENEPOP version 1.2: population genetics software for exact tests and ecumenicism. J Hered 86: 248-249.

Rice WR (1989). Analyzing tables of statistical tests. Evolution 43: 223-225.

Ryder OA (1986). Species conservation and systematics-the dilemma of subspecies. Trends Ecol Evol 1: 9-10.

Santucci F, Emerson BC, Hewitt GM (1998). Mitochondrial DNA phylogeography of European hedgehogs. Mol Ecol 7: 1163-1172.

Seddon JM, Santucci F, Reeve NJ, Hewitt GM (2001). DNA footprints of European hedgehogs, Erinaceus europaeus and
E. concolor: Pleistocene refugia, postglacial expansion and colonization routes. Mol Ecol 10: 2187-2198.

Stugren B (1966). Geographic variation and distribution of the Moor Frog, Rana arvalis Nilsson. Ann Zool Fenn 3: 29-39.

Svenning J-C, Skov F (2007). Could the tree diversity pattern in Europe be generated by postglacial dispersal limitation? Ecol Lett 10: 453-460.

Taberlet P, Swenson JE, Sandegren F, Bjärvall A (1995). Localization of a contact zone between two highly divergent mitochondrial DNA lineages of the brown bear (Ursus arctos) in Scandinavia. Conserv Biol 9: 1255-1261.

Takezaki N, Nei M (1996). Genetic distances and reconstruction of phylogenetic trees from microsatellite DNA. Genetics 144 389-399.

Tanaka-Ueno T, Matsui M, Sato T, Takenaka S, Takenaka O (1998). Local population differentiation and phylogenetic relationships of Russian brown frog, Rana amurensis inferred by mitochondrial cytochrome $b$ gene sequences (Amphibia, Ranidae). Jpn J Herp 17: 91-97.

Ursenbacher S, Carlsson M, Helfer H, Tegelström H, Fumagalli L (2006). Phylogeography and Pleistocene refugia of the adder (Vipera berus) as inferred from mitochondrial DNA sequence data. Mol Ecol 15: 3425-3437.

Vos CC, Antonisse-De Jong AG, Goedhart PW, Smulders MJM (2001). Genetic similarity as a measure for connectivity between fragmented populations of the moor frog (Rana arvalis). Heredity 86: 598-608.

Weir BS, Cockerham CC (1984). Estimating F-statistics for the analysis of population structure. Evolution 38: 1358-1370. 